\title{
EFFECTS OF PROCESS PARAMETERS ON FRICTION STIR WELDING OF 6063 ALUMINUM ALLOY
}

\author{
R. MuthuVaidyanathan ${ }^{(a)}$, MahaboobPatel ${ }^{(a)}, \quad$ N. SivaRaman ${ }^{(a)} ， \quad$ D. Tedwors $^{(a)}$ \\ a-Department of Mechanical Engineering, Wolaita Sodo University, Ethiopia
}

\begin{abstract}
Friction Stir Welding is a solid state joining technique which is widely being used for aerospace, marine, automotive and other applications for joining similar and dissimilar metals. Compared to other welding techniques friction stir welding (FSW) produces better mechanical properties in the weld zone. The main objective of this article is to find the optimum parameters for joining of butt joint aluminum alloy 6063. The major factors taken for investigations are rotational speed, transverse speed and axial force. The aim of this work determine the feasibility to weld two pieces of aluminum plate by friction stir welding and study the effect on the mechanical properties of welding joints. Friction stir welding machine has been used to attempt this welding and group of welding parameters. The Mechanical properties of welded joints were investigated using different mechanical tests including tensile testing and hardness testing. Process with a maximum welding efficiency in terms of ultimate tensile strength, using $1000(\mathrm{RPM})$ rotational speed, $1(\mathrm{~mm} / \mathrm{sec})$ traveling speed and axial load of $6000 \mathrm{~N}$.
\end{abstract}

Keywords: Friction stir welding (FSW), Analysis Variance, AA6063, Aluminium Alloy.

\section{INTRODUCTION}

Friction stir welding and its variation of friction stir processing (FSP), a solid-state joining and surface modification technique were invented at The Welding Institute of UK in 1991 (TWI, 2009). Application of FSW showed great promise in joining many ferrous and non-ferrous alloys that were joined by using conventional welding techniques with great difficulty. The convenience of the FSW as a joining technique has been demonstrated in a number of studies, especially for commercially pure aluminum. 
International Journal of Design and Manufacturing Technology (IJDMT), ISSN 0976 - 6995(Print), ISSN 0976 - 7002(Online), Volume 6, Issue 1, January - April (2015), pp. 01-09 @ IAEME

Friction stir welding process uses a non-consumable rotating tool consisting of a pin extending below a shoulder that is forced into the adjacent mating edges of the work pieces. The heat input, the forging action and the stirring action of the tool induces a plastic flow in the material, forming a solid state weld [1].Due to the absence of melting of the metal, the FSW process is observed to offer several advantages over fusion welding. There four different micro structural zones observed in a FSW weld such as: (i)Base Metal(BM) (ii)Heat Affected Zone(HAZ) (iii) Thermo mechanically affected Zone (TMAZ) \& (iv) Nugget Zone (NZ) [2]. Normally high welding speed ultimate tensile strength increases as compare to low welding speed in as welded condition but it is reverse after post weld heat treatment and the welding process softens the material significantly which decrease the hardness, tensile strength and increases the ductility of the material[3]. In welding, the heat input plays an important role on the mechanical properties of the weldments. The ultimate tensile strength increases with increase in weld speed in the tested range and decreasing the parameter tool rotational speed (TRS) increases the tensile strength. In FSW, it is understood that increasing the weld speed and decreasing the TRS, reduce the heat input required for joining leading to a reduction in the thickness of TMAZ and HAZ which, in turn, increases the tensile properties [4].

In addition to other defects, main problems are lack of enough heat because of high heat conductivity and sheets separation from fixture. Heat is notenough not because of small tool shoulder or in complete contact between shoulder and plates, it is because of highheat conductivity of aluminium which becomes higher because of low thickness of ultrathin plates. This problem can be solved using a resistant plate under main plates. When tool feeds towards the part of plates which are in front of tool leave fixture surface and scroll around tool and rupture occurred. For this problem one can use clamps closely together so a roll which moves in front of tool and prevents sheets to go upward can be used. Another problem is welding zone thinning that occurred in welding zone which is area son of rupture in welding zone during tensile test and cannot be prevented; in literature it is indicated that welding zone yield strength is $90 \%$ of parent metal[5]. To ensure a successful and efficient welding cycle the tool speed and tool geometry must be chosen with care, as both of these parameters are considerably important. [6]

\section{EXPERIMENTAL PROCEDURE}

\subsection{Material}

Aluminum 6063 alloy material is used for this investigation. The AA6063Material was cut by 150 x 100 x 5 mm size. Chemical composition of AA6063 is listed in Table1.

Table.1: Composition of AA 6063

\begin{tabular}{cccccccccc}
\hline Element & $\mathrm{Si}$ & $\mathrm{Fe}$ & $\mathrm{Cu}$ & $\mathrm{Mn}$ & $\mathrm{Mg}$ & $\mathrm{Zn}$ & $\mathrm{Ti}$ & $\mathrm{Cr}$ & $\mathrm{Al}$ \\
$\%$ & $0.2-0.6$ & 0.35 & 0.1 & 0.1 & $0.45-0.9$ & 0.1 & 0.1 & 0.1 & $\mathrm{Bal}$ \\
\hline
\end{tabular}

\subsection{Tool Design}

The tool must be made from a material which can withstand the process and offer enough frictional heat generation. When selecting a material from which to manufacture the 
International Journal of Design and Manufacturing Technology (IJDMT), ISSN 0976 - 6995(Print), ISSN 0976 - 7002(Online), Volume 6, Issue 1, January - April (2015), pp. 01-09 @ IAEME

FSW tool the material to be welded must be considered. The tool material must be sufficiently stronger and more wear resistant than the material to be welded and must also have a higher melting temperature [7]. A basic and conventional design for a FSW tool is shown in Figure 1. This cylindrical probe design will be compared to other more complex and still emerging tool variants. FSW tools follow the same basic trends in terms of their shapes and geometries. They are generally comprised of three generic features: 1) A shoulder section; 2) A probe and 3) Any external features on the probe. The shoulder is designed as a relatively large, when compared to the probe, profiled surface. Although the probe makes the initial contact with the pre-welded material the shoulder has a larger contact area and produces more friction.

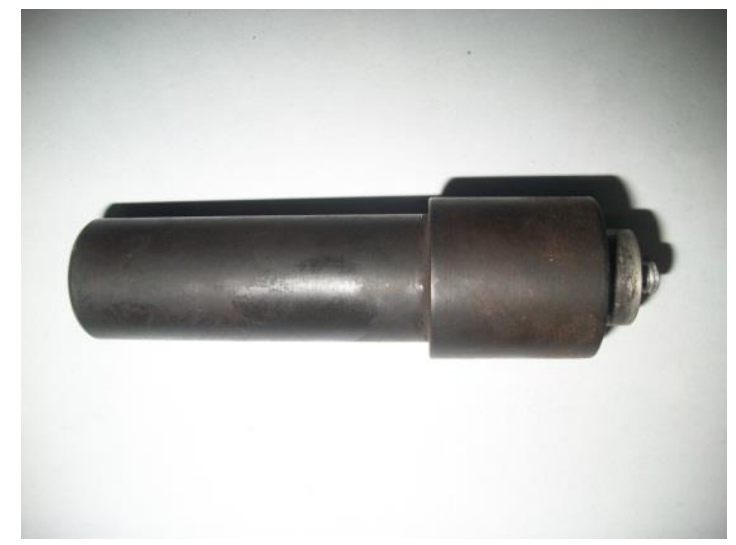

Figure.1: Weld Tool

\subsection{Welding Parameters}

For this study following parameters are mainly considered. They are

1. Axial Load (AF)

2. Transverse Speed (TS)

3. Rotational Speed (RS)

The different parameters taken for welding is given in the table.2.

\subsection{FSW Process}

The plates are placed in a butt configuration of $100 \mathrm{~mm}$ length; $150 \mathrm{~mm}$ width and the FSW process is carried out normal to the direction of the plates. The tool rotation is in the same direction of translation of the tool. First the two plates that should be welded kept in the bed and it is tightly fixed using the clamps in the bed. These clamps can hold the plates firmly even larger pressure or force is acted on it. The movement of the bed, rotation of the motor and the movement of the tool holder are done through the hydraulic devices and it is operated using the Control buttons which are present in the control panel in the FSW machine. The machine and assembly are shown in fig. 2 .

Table.2 Process Parameters

\begin{tabular}{lccc}
\hline Sl. No & $\begin{array}{c}\text { RS } \\
(\mathbf{r p m})\end{array}$ & $\begin{array}{c}\text { T.S } \\
(\mathbf{m m} / \mathbf{s})\end{array}$ & $\begin{array}{c}\text { A.L } \\
(\mathbf{N})\end{array}$ \\
\hline
\end{tabular}


International Journal of Design and Manufacturing Technology (IJDMT), ISSN 0976 - 6995(Print), ISSN 0976 - 7002(Online), Volume 6, Issue 1, January - April (2015), pp. 01-09 @ IAEME

\begin{tabular}{cccc}
\hline $\mathbf{1}$ & 1000 & 0.5 & 4000 \\
$\mathbf{2}$ & 1000 & 1 & 6000 \\
$\mathbf{3}$ & 1500 & 1 & 4000 \\
$\mathbf{4}$ & 1500 & 0.5 & 6000 \\
\hline
\end{tabular}

A set of 4 specimens for determining the mechanical properties were prepared by using a wire cut EDM machine as shown in Figure 4a -4.d.

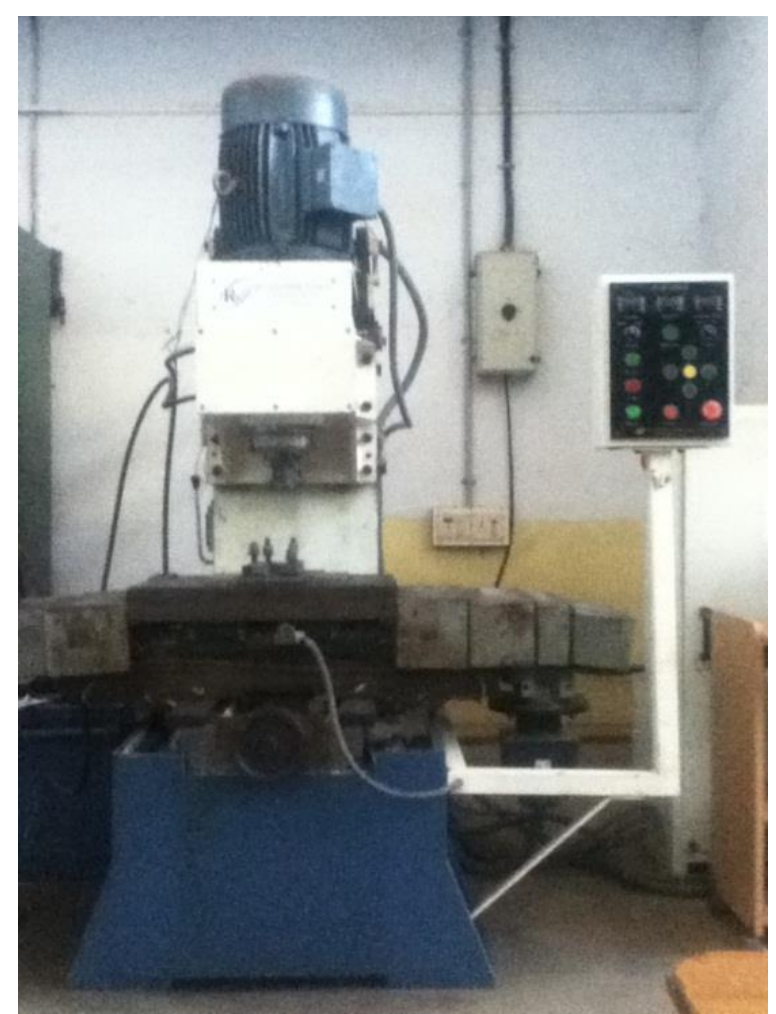

Figure.2: Friction Welding Machine

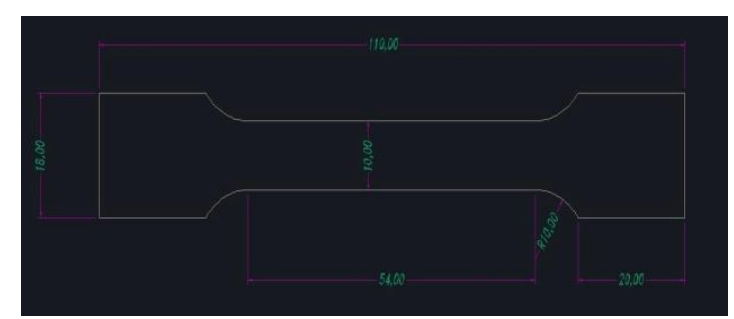

Fig.3 
International Journal of Design and Manufacturing Technology (IJDMT), ISSN 0976 - 6995(Print), ISSN 0976 - 7002(Online), Volume 6, Issue 1, January - April (2015), pp. 01-09 @ IAEME

TEST SAMPLE ID A

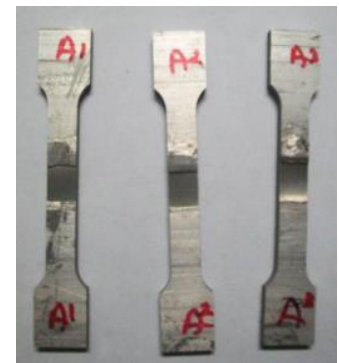

Fig.4.a

TEST SAMPLE ID C

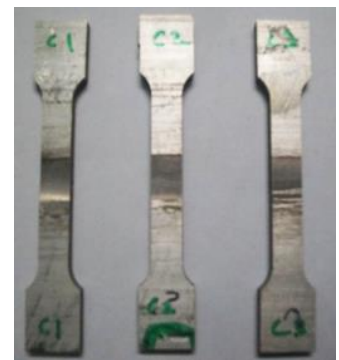

Fig.4.c
TEST SAMPLE ID B

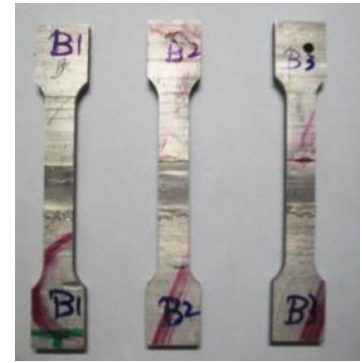

Fig.4.b

TEST SAMPLE ID D

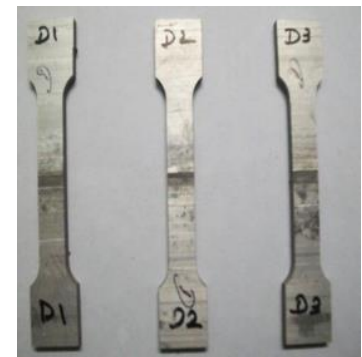

Fig.4.d

\section{RESULTS AND DISCUSSIONS}

In the present work, different FSW butt welds were obtained by varying the process parameters within the range and the optimal values are drawn based on the trend of the values. The weld joints are tested for tensile strength and hardness strength.

\subsection{TENSILE TESTING}

The specimens for tensile test were prepared according to the guidelines of American Society for Testing of Materials (ASTM) as shown in Fig3. Test was carried out Universal Testing Machine at a room temperature. The specimen finally failed after necking and the load versus displacement was recorded UTM for Table 3 describes the specimen specifications used on the testing and table- 4 is mean values of various sample. The tensile tested pieces are shown Fig.5a-5d.

TESTED SAMPLES

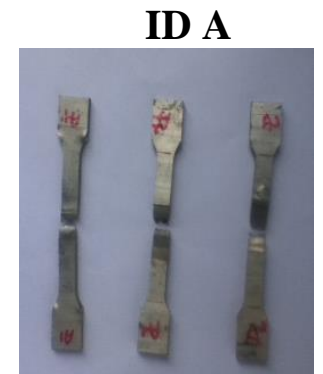

Fig.5.a
ID B

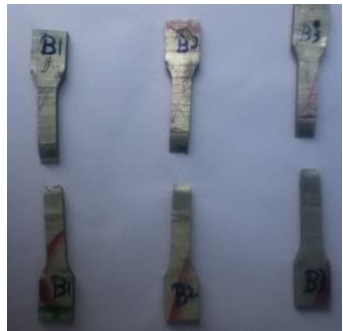

Fig.5.b 
International Journal of Design and Manufacturing Technology (IJDMT), ISSN 0976 - 6995(Print), ISSN 0976 - 7002(Online), Volume 6, Issue 1, January - April (2015), pp. 01-09 @ IAEME

ID C

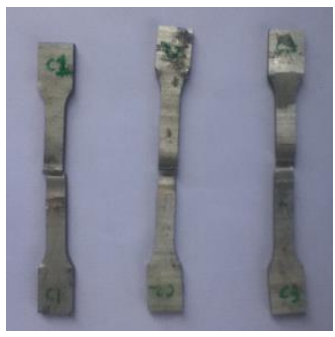

Fig.5.c
ID D

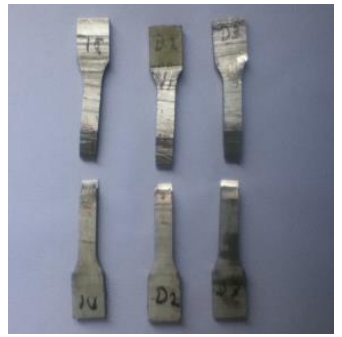

Fig.5.d

Table.3: Tensile Test Results for various process parameters

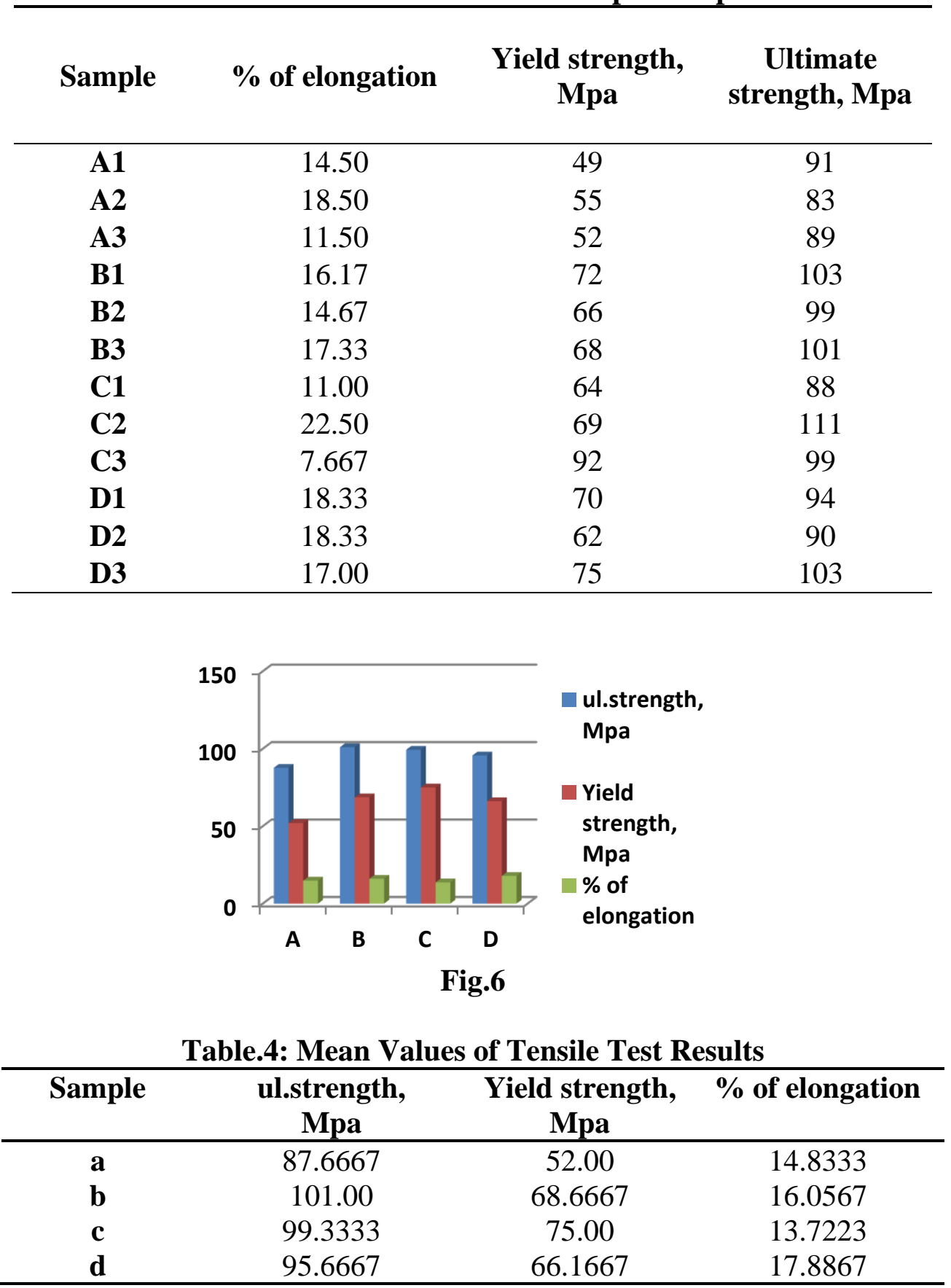


International Journal of Design and Manufacturing Technology (IJDMT), ISSN 0976 - 6995(Print), ISSN 0976 - 7002(Online), Volume 6, Issue 1, January - April (2015), pp. 01-09 @ IAEME

\subsection{Hardness Test}

Each mould sample is placed on the vicker's Micro hardness machine and hardness survey is seen on 3 portions namely Parent metal, HAZ and nugget zone. Each value is plotted in the table 5. In fig. 7 hardness of various zones is plotted for different samples.

Table 5: Hardness Test Values

\begin{tabular}{lllll}
\hline Hardness & \multicolumn{4}{c}{ Sample } \\
\cline { 2 - 5 } Location. & "A" & "B" & "C" & "D" \\
\hline Parent metal & 45.1 & 46.0 & 42.2 & 37.9 \\
HAZ Zone & 46.5 & 46.4 & 46.2 & 46.5 \\
Nugget Zone & 44.4 & 46.1 & 47.2 & 47.3 \\
\hline
\end{tabular}

\subsection{Statistical analysis}

The statistical analysis of the data was made in two phases. The first phase was concerned with the analysis of variance with the effect of process parameters and their interactions in table.7. The second phase was concerned with correlation of input parameters and properties of friction stir weld.

- In the table-6, the $\mathrm{F}$ value 0.507 for the mean difference in the percentage of elongation among the different types of samples $(\mathrm{A}, \mathrm{B}, \mathrm{C}, \mathrm{D})$ is not significant $(\mathrm{p}<0.688)$. It means that the percentage of elongation among the samples were similar.

- Regarding the yield of strength, the F value 4.122 for the mean difference in the yield of strength among the different types of samples (A, B, C, D) is significant $(p<0.048)$. It means that there is a significant difference in the yield of strength between the samples. The mean yields of strength of the samples (A, B, C, D) were 58.000, 68.666, 75.000 and 69.000 respectively. Further in the post hoc analysis it reveals that the yield of strength of sample $\mathrm{C}$ is significantly higher when compared to other samples.

- While comparing the ultimate strength, the above table $\mathrm{F}$ value 2.134 for the mean difference in the ultimate strength among different types of samples (A, B, C, D) is not significant $(p<0.174)$. It means that the ultimate strength of the samples were similar.

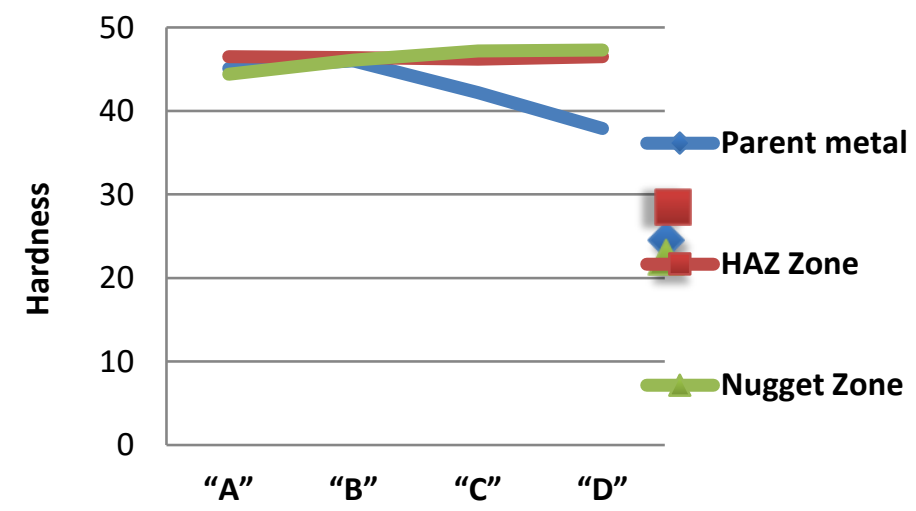

Fig.7 
International Journal of Design and Manufacturing Technology (IJDMT), ISSN 0976 - 6995(Print), ISSN 0976 - 7002(Online), Volume 6, Issue 1, January - April (2015), pp. 01-09 @ IAEME

Table- 6: Descriptive of Samples A, B,C and D

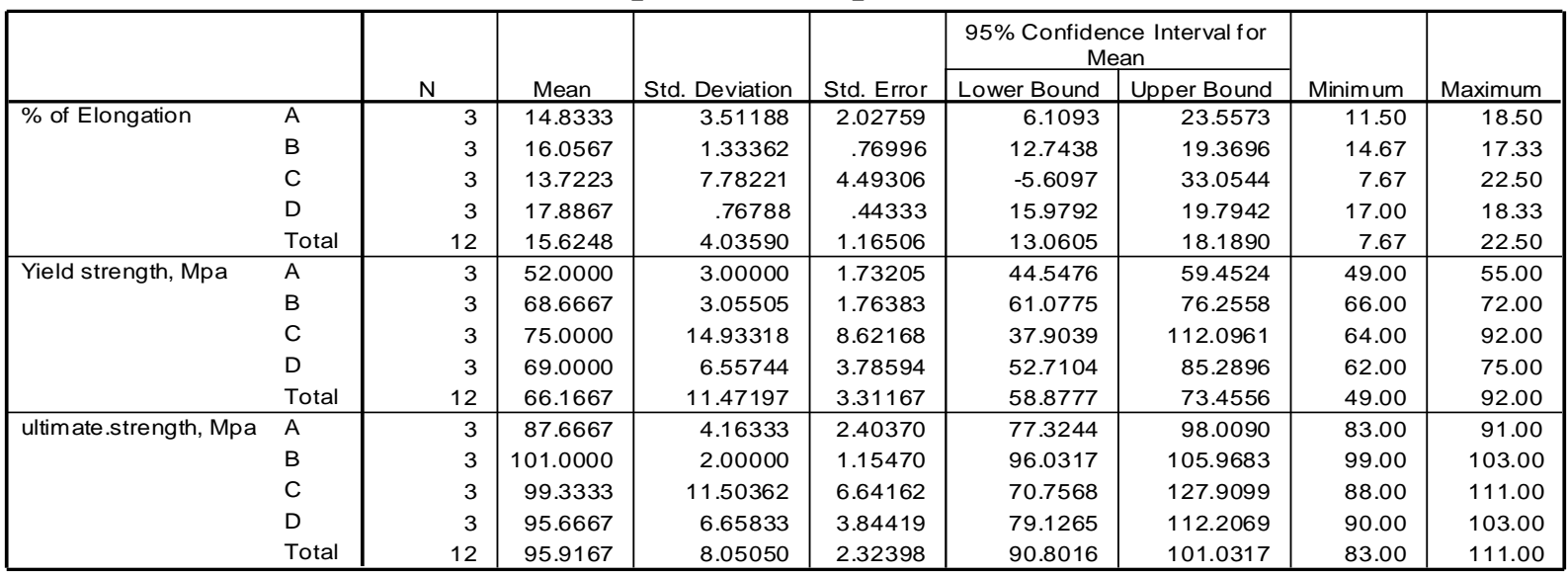

Table- 7: ANOVA

\begin{tabular}{|c|c|c|c|c|c|c|}
\hline & & $\begin{array}{l}\text { Sum of } \\
\text { Squares }\end{array}$ & df & Mean Square & $\mathrm{F}$ & Sig. \\
\hline$\%$ of Elongation & $\begin{array}{l}\text { Between Groups } \\
\text { Within Groups } \\
\text { Total }\end{array}$ & $\begin{array}{r}28.645 \\
150.529 \\
179.174 \\
\end{array}$ & $\begin{array}{r}3 \\
8 \\
11 \\
\end{array}$ & $\begin{array}{r}9.548 \\
18.816\end{array}$ & .507 & .688 \\
\hline Yield strength, Mpa & $\begin{array}{l}\text { Between Groups } \\
\text { Within Groups } \\
\text { Total }\end{array}$ & $\begin{array}{r}879.000 \\
568.667 \\
1447.667 \\
\end{array}$ & $\begin{array}{r}3 \\
8 \\
11 \\
\end{array}$ & $\begin{array}{r}293.000 \\
71.083\end{array}$ & 4.122 & .048 \\
\hline ultimate.strength, Mpa & $\begin{array}{l}\text { Between Groups } \\
\text { Within Groups } \\
\text { Total }\end{array}$ & $\begin{array}{l}316.917 \\
396.000 \\
712.917\end{array}$ & $\begin{array}{r}3 \\
8 \\
11\end{array}$ & $\begin{array}{r}105.639 \\
49.500\end{array}$ & 2.134 & .174 \\
\hline
\end{tabular}

\section{CONCLUSION}

The butt joining of Aluminum alloy AA6063 was successfully carried out using FSW technique. The samples were characterized by mechanical properties. The following conclusions were made from the present investigation.

- The optimum operating conditions of FSW have been obtained for two plates of aluminium alloy AA6063 welded in but tjoint.

- From the experimental results the better performance is occurred at B1B3C2D3.

- A maximum mean ultimate stress of (101Mpa) exhibited by tool with optimal process parameters of tool rotational speed, $1000 \mathrm{rpm}$; axial force, $6000 \mathrm{~N}$ and transverse speed of $1 \mathrm{~mm} / \mathrm{sec}$.

- Axial force and rotational speeds are the dominant parameter for equivalent stress developed on the too 1 followed by rotational speed.

- It is found that percentage of elongation is less for all the specimens, which show the amount of heat generated in the process is less.

- Hardness of sample-B is comparatively high in all zones of among the different sample.

- From the ANOVA, it is concluded that the weld speed is the main input parameter that has the highest statistical influence on mechanical properties like, tensile strength, elongation and hardness. 
International Journal of Design and Manufacturing Technology (IJDMT), ISSN 0976 - 6995(Print), ISSN 0976 - 7002(Online), Volume 6, Issue 1, January - April (2015), pp. 01-09 @ IAEME

\section{REFERENCES}

[1]. Mukuna P. Mubiayi. and Esther T. Akinlabi, "Friction Stir Welding of Dissimilar Materials between Aluminium Alloys and Copper - An Overview"Proceedings of the World Congress on Engineering 2013 Vol III, WCE 2013, July 3 - 5, 2013, London, U.K.

[2]. C.J. Dawes and W.M. Thomas, (1996), Weld. J., Vol. 75, p 41.

[3]. Ratnesh Kumar Raj Singh, "Effect of Friction Stir Welding on Mechanical Properties of Dissimilar Aluminium Alloys" National Conference on Innovative Paradigms in Engineering \& Technology (NCIPET-2012), Proceedings published by International Journal of Computer Applications (IJCA).

[4]. N Rajamanickam\& V Balusamy, "Effects of process parameters on mechanical properties of friction stir welds using design of experiments" Indian Journal of Engineering \& Materials Sciences. Vol. 15, August 2008, pp. 293-299.

[5]. S. Sattari, H. Bisadi, M. Sajed," Mechanical Properties and Temperature Distributions of Thin Friction Stir Welded Sheets of AA5083" International Journal of Mechanics and Applications 2012, 2(1): 1-6. DOI: 10.5923/j.mechanics.20120201.01.

[6]. Ram Kumar, M. Siva Pragash and Saji Varghese, "Optimizing the Process Parameters of FSW on AZ31B Mg Alloy by Taguchi-Grey Method" Middle-East Journal of Scientific Research 15 (1): 161-167, 2013 IDOSI Publications, 2013 DOI: 10.5829/idosi.mejsr.2013.15.1.2246.

[7]. A M Khourshid and I Sabry, "Analysis and Design of Friction Stir Welding", International journal of Mechanical engineering and robotics research, Vol. 2, No. 3, July 2013.

[8]. Kuk Hyun Song and Kazuhiro Nakata," Mechanical Properties of Friction-Stir-Welded Inconel 625 Alloy" Materials Transactions, Vol. 50, No. 10 (2009) pp. 2498 to 2501.

[9]. S. Ravikumar, V. SeshagiriRao and R.V. Pranesh "Effect of Process Parameters on Mechanical Properties of Friction Stir Welded Dissimilar Materials between AA6061T651 and AA7075-T651 Alloys", International Journal of Advanced Mechanical Engineering.Volume 4, Number 1 (2014), pp. 101-114.

[10]. N Rajamanickama\& V Balusamy "Effects of process parameters on mechanical properties of friction stir welds using design of experiments" Indian Journal of Engineering \& Materials Sciences. Vol. 15, August 2008, pp. 293-299.

[11]. PuneetRohilla, Narinder Kumar "Experimental investigation of Tool Geometry on Mechanical Properties of Friction Stir Welding of AA6061'International Journal of Innovative Technology and Exploring Engineering (IJITEE), Volume-3, Issue-3, August 2013.

[12]. D.Muruganandam and Dr.Sushil lal Das,, "Friction Stir Welding Process Parameters for Joining Dissimilar Aluminum Alloys", International Journal of Mechanical Engineering \& Technology (IJMET), Volume 2, Issue 2, 2011, pp. 25 - 38, ISSN Print: 0976 - 6340, ISSN Online: 0976 - 6359.

[13]. D. Kanakaraja, P. Hema and K. Ravindranath, "Comparative Study on Different Pin Geometries of Tool Profile in Friction Stir Welding using Artificial Neural Networks", International Journal of Mechanical Engineering \& Technology (IJMET), Volume 4, Issue 2, 2013, pp. 245 - 253, ISSN Print: 0976 - 6340, ISSN Online: 0976 - 6359. 